\title{
Alternative grains in nutrition
}

\author{
Sz. Jevcsák \\ P. Sipos \\ e-mail: jevcsak@agr.unideb.hu \\ e-mail: siposp@agr.unideb.hu

\begin{abstract}
University of Debrecen, Faculty of Agricultural and
Food Sciences and Environmental Management, Institute of Food Technology,

H-4032 Debrecen, Böszörményi u. 138. Hungary
\end{abstract}

\begin{abstract}
Many people suffer from gluten sensitivity or gluten intolerance. They have to avoid or limit their gluten intake. Sorghum and millet are gluten-free cereals, wherefore persons with gluten sensitivity or gluten intolerance could consume them. Moreover, they have a lot of positive effects due to their phenolic compounds as phenol acid or flavonoid. Antioxidant activity in sorghum is especially high in comparison with other cereals. Our aim was to compare literature data about the chemical compositions of sorghum and millet with other grains.
\end{abstract}

\section{Introduction}

Sorghum and millet have an important role in the semi-arid tropics of Asia and Africa. These crops are the main sources of energy, protein, vitamins, and minerals for millions of the poorest people in these regions (FAO, 1995). Due to their antioxidant activity, they have a great benefit for the human organism. They have a positive effect on gut microbiota and work as inhibitors of chronic diseases (obesity and cancer). Moreover, sorghum contains carotenoids and has a high content of vitamin E (Cardoso et al., 2015).

Keywords and phrases: gluten, sorghum, millet, chemical compositions 


\subsection{Alternative grains}

Sorghum and millet are alternative grains, which are cultivated in small areas. Their uses are mostly traditional (Berényi, 2013). There are major emerging uses for gluten-free food and beverage products (Taylor \& Duodu, 2010).

\section{Sorghum}

Sorghum bicolor (L.) is the fifth most important cereal in the world after rice, wheat, maize, and barley (Food Security Department, 1999). It can grow under excessive heat or in infertile soils (Mokrane et al., 2010). The sorghum's area is 42 million ha. The biggest part is situated in Africa (24,5 million ha) and in Asia (10,6 million ha). In India, this number is 9,1 million ha, in USA is 6,6 million ha, and in Australia is 0,7 million ha (Kiran, 2014). The crop is suited to hot and dry agroecologies. Sorghum production includes two groups:

- group I countries (mainly in Asia and Africa) use sorghum for food;

- group II countries (developed and some developing countries) produce sorghum for animal feed. The crop yields an average of $3-5 \mathrm{t} / \mathrm{ha}$ (FAO, 1996).

Sorghum has the following species:

- Sorghum vulgare Pers var. technicum

- Sorghum vulgare Pers var. saccharatum

- Sorghum vulgare Pers var. frumentaceum

- Sorghum vulgare Pers var. sudanense (Németh, 2009).

\section{Millet}

Millet (Panicum miliaceum L.) is a small-grained cereal. The most important strains of millets are:

- pearl millet (Pennisetum glaucum);

- finger millet (Eleusine coracona);

- proso millet (Panicum miliaceum);

- foxtail millet (Stalia italica).

The genus Pennisetum includes about 140 species, which include domesticated and wild-growing species. Millet areas are distributed in most of the Asian and African countries and also parts of Europe (Kajunas, 2001). Developing countries account for $94 \%$ of global output and an estimated 28 million tons: pearl millet -15 million tons, foxtail millet -5 million tons, proso millet -4 million tons, finger millet -3 million tons (FAO, 1996). 


\subsection{Chemical compositions of sorghum and millet}

Sorghum provides several benefits such as essential fatty acids, proteins, carbohydrates, energy, minerals, vitamins, phytic acid, carotenoids, alcohols, flavonoids, phenolic acids, and bioactives (Abugri et al., 2013). Due to lysine, sulphur-containing amino acids, threonine and tryptophan, millet has a good amino acid balance (Ajiboye et al., 2014).

Table 1: Chemical parameters of cereals (\% dry matter)

\begin{tabular}{lrrrr}
\hline \multicolumn{1}{c}{ Cereals } & Starch & Protein & Ash & Raw fat \\
\hline Hard wheat & 77.4 & 13.5 & 0.56 & 0.98 \\
Soft wheat & 77.9 & 11.0 & 0.71 & 0.86 \\
Barley & 53.6 & 19.4 & 2.88 & 2.31 \\
Rye & 58.0 & 13.3 & 1.96 & 2.53 \\
Sorghum & 67.7 & 12.1 & 1.87 & 3.32 \\
Millet & 67.4 & 8.8 & 1.82 & 4.22 \\
\hline
\end{tabular}

According to Bagli (2008)

The protein content in sorghum is $12.1 \%$, the protein content in millet is $8.8 \%$ (Table 1). The protein content in sorghum is quite variable. In most literatures, this value ranges from 6 to 16\% (Mokrane et al., 2010). The starch content in these grains is approximately equal $(67 \%)$. The raw fat content in millet is $4.22 \%$; therefore, the energy content is very high in this grain (Table 1 ).

Both grains have a large content of leucine: in sorghum: $832 \mathrm{mg} / \mathrm{kg}$, in millet: $598 \mathrm{mg} / \mathrm{kg}$. However, the phenylalanine and isoleucine content are also high in these cereals. The amount of valine and threonine is high as well; consequently, the essential amino acid composition in sorghum and millet is great (Table 2).

The mineral content in millet is very high compared with other cereals; it is especially rich in $\mathrm{P}, \mathrm{K}, \mathrm{Mg}, \mathrm{Ca}$, and Fe. Sorghum has a lot of $\mathrm{P}, \mathrm{K}$, and $\mathrm{Mg}$ (Table 3). 
Table 2: Essential amino acid composition $(\mathrm{mg} / \mathrm{kg})$ and chemical score of sorghum and millet proteins

\begin{tabular}{lrr}
\hline & Sorghum & Pearl millet \\
\cline { 2 - 3 } Isoleucine & 245 & 256 \\
Leucine & 832 & 598 \\
Lysine & 126 & 214 \\
Methionine & 87 & 154 \\
Cystine & 94 & 148 \\
Phenylalanine & 306 & 301 \\
Tyrosine & 167 & 203 \\
Threonine & 189 & 241 \\
Tryptophan & 63 & 122 \\
Valine & 313 & 345 \\
Chemical score & 37 & 63 \\
\hline
\end{tabular}

According to Bagli (2008)

Table 3: Mineral content of cereals $(\mathrm{mg} / \mathrm{kg})$

\begin{tabular}{lrrrrrr}
\hline & Hard wheat & Soft wheat & Barley & Sorghum & Rye & Millet \\
\hline $\mathrm{P}$ & 3498 & 977.6 & 4570 & 349.9 & 3620 & 2879 \\
$\mathrm{~K}$ & 826.2 & 1225 & 4572 & 239.9 & 3570 & 2798 \\
$\mathrm{Mg}$ & 301.2 & 306.5 & 1971 & 187.7 & 1328 & 1488 \\
$\mathrm{Ca}$ & 159.5 & 202.2 & 736.2 & 27.3 & 348.7 & 508.6 \\
$\mathrm{Na}$ & 46 & 38.4 & 238.4 & 4.6 & 67.2 & 60.89 \\
$\mathrm{Zn}$ & 30.8 & 7.6 & 74.2 & 3.1 & 30.6 & 65.9 \\
$\mathrm{Fe}$ & 13.2 & 13.9 & 128.4 & 10.6 & 44 & 199.8 \\
$\mathrm{Mn}$ & 5.2 & 8.1 & 9.2 & 1.2 & 24.4 & 8.1 \\
$\mathrm{Cu}$ & 1.4 & 1.6 & 5.7 & 0.2 & 2.9 & 3.4 \\
$\mathrm{Cr}$ & 0.1 & 0.001 & 0.9 & 0.8 & 0.7 & 7.7 \\
\hline
\end{tabular}

According to Bagli (2008)

Sorghum has the highest phenol content among cereals and the most intensive antioxidant activity. The phenolic compounds are $4128 \mu \mathrm{g} / \mathrm{g}$, while in wheat this amount is only between 501 and $562 \mu \mathrm{g} / \mathrm{g}$. The antioxidant capacity in sorghum is $195.8 \mu \mathrm{mole} / \mathrm{g}$, while in wheat it is only $4.17-4.33 \mu \mathrm{mole} / \mathrm{g}$ (Table 4). 
Table 4: Antioxidant activity and phenol compounds of cereals

\begin{tabular}{|c|c|c|c|}
\hline Cereals & $\begin{array}{l}\text { Phenol } \\
\text { compounds } \\
\text { (gallic acid } \\
\text { equivalents) } \\
(\mu \mathrm{g} / \mathrm{g})\end{array}$ & $\begin{array}{l}\text { "DPPH" } \\
\text { antioxidant capacity } \\
\text { after } 10 \text { minutes } \\
(\mu \text { mole/g), } \\
\text { "ABTS" }\end{array}$ & $\begin{array}{l}\text { "ABTS" } \\
\text { antioxidant } \\
\text { capacity after } 3 \\
\text { minutes } \\
(\mu \mathrm{mole} / \mathrm{g})\end{array}$ \\
\hline Hard wheat & 562 & 4.33 & 8.8 \\
\hline Soft wheat & 501 & 4.17 & 8.3 \\
\hline Barley & 879 & 21.00 & 14.9 \\
\hline Sorghum & 4128 & 195.8 & 51.7 \\
\hline Rye & 1026 & 12.17 & 13.0 \\
\hline Millet & 1387 & 23.83 & 21.4 \\
\hline
\end{tabular}

According to Bagli (2008)

Table 5: Dietary fibre in cereals (\% dry matter)

\begin{tabular}{lcccc}
\hline \multicolumn{1}{c}{ Cereals } & $\begin{array}{l}\text { Soluble } \\
\text { dietary fibre }\end{array}$ & $\begin{array}{l}\text { Resistant } \\
\text { starch }\end{array}$ & $\begin{array}{l}\text { Insoluble } \\
\text { dietary fibre }\end{array}$ & $\begin{array}{c}\text { Total dietary } \\
\text { fibre content }\end{array}$ \\
\hline Hard wheat & 1.61 & 0.20 & 2.98 & 4.59 \\
Soft wheat & 1.78 & 0.55 & 1.87 & 3.65 \\
Barley & 2.56 & 0.23 & 22.07 & 24.63 \\
Sorghum & 1.42 & 1.77 & 19.59 & 21.01 \\
Rye & 3.70 & 0.20 & 14.07 & 17.77 \\
Millet & 1.45 & 1.96 & 13.50 & 14.95 \\
\hline
\end{tabular}

According to Bagli (2008)

Sorghum contains $21 \%$ of total dietary fibre content. The insoluble dietary fibre is also high, $19.59 \%$. The total dietary fibre content in millet is lower, $14.95 \%$; otherwise, the soluble dietary fibre in sorghum (1.42\%) and in millet $(1.45 \%)$ is approximately equal ( Table 5). Waxy starch includes about $100 \%$ amylopectin, while non-waxy sorghum starch has $75 \%$ amylopectin and $25 \%$ amylose (Wong et al., 2009).

Finger millet contain phytates $(0.48 \%)$, polyphenols, tannins $(0.61 \%)$, trypsin inhibitors, and fibres, which have antinutrient effects due to chelating and inhibitor activities (Palanisamy et al., 2014). Finger millet, from cereals, is a rich source of $\mathrm{Ca}$, containing 300 to $350 \mathrm{mg} / 100 \mathrm{~g}$ of it (Kiran, 2014). 


\subsection{Utilization as food}

During the past few years, sorghum and millet production has increased. Sorghum is used as steamed, leavened, and fat-fried product (FAO, 1995). Furthermore, sorghum use is similar to that of corn: starch, glucose, syrup, and oil can be produced. Moreover, it can be used in preparing whole-grain products, bread, pancake, dumpling, mush, cake, pasta, and beer. Broom and forage can also be prepared from them. Millet is used as traditional food and beverage products, with malting and lactic acid fermentation technologies (Taylor \& Kruger, 2016).

\section{Conclusions}

Sorghum and millet have a great essential amino acid composition. The mineral content in millet is very high in comparison with other cereals; it is especially rich in $\mathrm{P}, \mathrm{K}, \mathrm{Mg}, \mathrm{Ca}$, and $\mathrm{Fe}$. Sorghum has the highest phenolic compounds among cereals and the most intensive antioxidant activity.

\section{References}

[1] D. A. Abugri, B. J. Tiimob, V. A. Apalangya, G. Pritchett, W. H. McElhenney, Bioactive and nutritive compounds in Sorghum bicolor (Guinea corn) red leaves and their health implication. Food Chemistry, 138. (2013) 718-723.

[2] T. O. Ajiboye, G. A. Iliasu, A. O Adeleye, F. A. Abdussalam, S. A. Akinpelu, S. M. Ogunbode, S. O. Jimoh, O. B. Oloyede, Nutritional and antioxidant dispositions of sorghum/millet-based beverages indigenous to Nigeria. Food Science \& Nutrition, 2. (2014) 597-604.

[3] A. Bagdi, Hántolt és hántolatlan köles táplálkozástani jellemzése és köles hozzáadásával készült tészta funkcionális tulajdonságainak vizsgálata. (Nutrition value of whole and hulled millet and measurement of functional parameters of pasta with added millet). Budapesti Müszaki és Gazdaságtudományi Egyetem, Budapest, (2008) 22, 24, 26.

[4] J. Berényi, Növénytermesztés a fenntartható tanyai gazdálkodási model szolgálatában. (Plant production for the sustainable small farm economic modell). Mezögazdasági Kutatóintézet, Újvidék, (2013) 263. 
[5] L. de M. Cardoso, S. S. Pihenheiro, L. Linhares de Silva, C. Beserra de Menezes, C. W. Piler de Carvolho, F. D. Tardin, V. A. V. Queiroz, H. S. D. Martino, H. M. Pinheiro-Sant'Ana, Tocochromanols and carotenoids in sorghum (Sorghum bicolor L.): Diversity and stability to the heat treatment. Food Chemistry, 172. (2015) 900-908.

[6] FAO Corporate Document Repository, Sorghum and millets in human nutrition, Rome, (1995).

[7] FAO Corporate Document Repository, The world Sorghum and millet economies: facts, trends and outlook. Food and Agriculture Organizations of the United Nations. Rome, (1996).

[8] Food Security Department, SORGHUM: Post-harvest operations. Food and Agriculture Organization of the United Nations, (1999) 2.

[9] S. T. R. Kajunas, Millet: Post-harvest operations. Food and Agricultural Organisation, 5. (2001) 1-49.

[10] D. K. Kiran, J. Alok, S. Latha, A. K. Singh, Significance of coarse cereals in health and nutrition: a review. Journal of Food Science and Technology, 51. (2014) 1429-1441.

[11] H. Mokrane, H. Amouria, N. Belhaneche-Bensemra, M. C. Courtin, A. J. Delcour, B. Nadjemi, Assessment of Algerian sorghum protein quality [Sorghum bicolor (L.) Moench] using amino acid analysis and in vitro pepsin digestibility. Food Chemistry, 121. (2010) 719-723.

[12] T. Németh, A tápanyagellátás hatása a silócirok (Sorghum bicolor L./Moench) tápelem-felvételére, szárazanyag-felhalmozására és terméshozamára. (Effect of nutrient supply on nutrient uptake, dry matter accumulation and yield of sweet sorghum (Sorghum bicolor L./Moench)). Debreceni Egyetem, Növénytudományi Intézet, Debrecen, (2009) 4.

[13] B. D. Palanisamy, V. Rajendran, S. Sathyaseelan, G. M. Nagappa, B. P. Venkatesan, Health benefits of finger millet (Eleusinecoracana L.) polyphenols and dietary fiber: a review. Journal of Food Science and Technology, 51. (2014) 1021-1040.

[14] J. R. N. Taylor, K. G. Duodu, Sorghum and millets: characteristics and quality requirements. Cereal Grains, (2010) 237-263. 
[15] J. R. N. Taylor, J. Kruger, Millets. Encyclopedia of Food and Health, (2016) 748-757.

[16] J. H. Wong, T. Lau, N. Cai, J. Singh, J. F. Pedersen, W. H. Vensel, W. J. Hurkman, J. D. Wilson, P. G. Lemaux, B. B. Bauchana, Digestibility of protein and starch from sorghum (Sorghum bicolor) is linked to biochemical and structural features of grain endosperm. Journal of Cereal Science, 49. (2009) 73-82. 